\title{
POLITICAL CORRUPTION AND ECONOMIC DEVELOPMENT IN NIGERIA
} https://doi.org/10.47743/jopafl-2021-20-16

\author{
Ejiroghene Augustine OGHUVBU \\ Department of History and International Studies \\ Faculty of Arts, Delta State University, Abraka \\ augustine4best@yahoo.com
}

\begin{abstract}
Scholars in the humanities and social sciences have observed that political corruption is a serious problem to the economic, social and political development of any nation. These problems or challenges have had negative effects on Nigeria economic development. Corruption, like cockroaches, has coexisted with human civilization for a long time and continues to be a concern in many developed and developing economies around the world, with disastrous results to economic development. Corruption as a phenomenon is a global issue of differing degrees and it's prevalent in various countries. This paper therefore, investigates the reasons, and impacts of corruption which are seen to be ingrained in socio-cultural traditions as well as the country's political and economic condition. The analysis also looked at the numerous government policies and programs use to combat corruption. The study collected its data primarily from academic journals, books, conference papers and internet sources. The study adopted the elite theory to explain corruption and its effects on economic development in Nigeria. The study found out that corruption results in the depletion of much needed revenue, discourages foreign investments and consequently slows economic development. It also reveals that corruption weakens domestic financial systems, tarnishes the country's reputation, lowers savings investment and lowers people's living standards. On this basis, the study proposes that the Nigerian government should address the root causes of corruption rather than the effects and this has to be through the effective implementation of legal mechanism.
\end{abstract}

Keywords: Corruption, Causes, Economic Growth, Economic Development, Nigeria.

\section{Introduction}

Scholars in the humanities and social sciences have noticed how political corruption has become a serious problem to economic, social and political development of any nation. Corruption, like cockroaches, has coexisted with human civilization for a long time and continues to be a concern in many developed economies around the world, with disastrous results to economic development. Corruption as a phenomenon is a global issue of differing degrees and its prevalence in various countries (Alege, Adamu \& Muhammad, 2014: 209). Corruption exists in both elected and dictatorial governments, as well as feudal, imperialist, and socialist economies. Corruption plagues Christian, Muslim, Hindu, and Buddhist communities in equal measures (Dike, 2005). Investigations into crude petroleum subsidy theft in Nigeria, illegal misappropriation of pension funds, and the recycling of items in the 2012 Budget, among other things, shows evidence of corrupt practices in the Nigerian political system (Rotimi, Obasaju, Lawal \& Iseolonunkanmi, 2013). In highly corrupt countries, the vicious cycle of poverty continues: poor savings result in lower salaries and benefits, which results in lower consumption and growth. Corruption's harmful consequences continue to stifle economic development and growth, create insecurity for citizens' lives and property, as shown by numerous Boko Haram attacks heightened level 
of unemployment and poverty. Dilapidation of infrastructure is a widespread occurrence, and it is primarily as a result of very-high prevalence of corruption which has exploded to unprecedented level (Rotimi, et al., 2013:2). It is one of the many unresolved issues in Nigeria, according to Madichie (2005:322) that has severely hampered and distorted growth. It will continue to be a big political and economic problem for Nigeria in the long run (Maduagwe, 1996). It's a canker worm that's eaten its way deep into the country's political system. Petty corruption, political/bureaucratic corruption, and systemic corruption are all examples of corruption. According to World Bank estimates, corruption costs over $\$ 1$ trillion annually, accounting for up to $12 \%$ of the GDP in countries like Nigeria, Kenya, and Venezuela (Alege, et al., 2014:209). It's on this note therefore, this study will fill a gap in literature to address the effects of corruption that takes place in the political system Vis-a-vis how it affects economic development in Nigeria's fourth republic.

\section{Concept of Corruption}

Corruption is widespread in Nigeria, and it is on the rise, despite many efforts by successive governments to address the issue. This has led to the issue of the concept been talked about by every Nigerian and seen as the major reason for the country's economic woes. Corruption has been the norm in Nigeria, affecting both the youthful and the aged, politicians and non-politicians, as well as military and non-military personnel (Igiebor, 2019:495). To various thinkers from various fields of thought, the unstoppable socio economic scourge has proposed various definitions. According to the International Monetary Fund (IMF) (2000) cited in Adetayo (2019: 23) described corruption as the "misuse of power or confidence for personal gain, and it is a not just governmental officials, but also people in positions of authority in private corporations or non-profit organizations." Corruption can take place in various ways such as 'kick back' a type of bribery in which someone engaged in the purchasing process receives a reward from the supplier for placing an order of goods or services; embezzlement: theft of resources for personal gain; evidence destruction; irregular destruction, removal, or abuse of records; extortion: the act of obtaining something by threat, force, or undue demands; favoritism: the unfair favoring of one person or group over another (Adetayo, 2019:23). These are among other ways corruption takes place in societies. Similarly, Ofoeze (2004:20) cited in Igiebor (2019: 495) Corruption is deliberate action or inaction by a person or group be it public or private to obtain benefits for oneself, a relation, associate, or group in a way that breaches established rules, ethics, and/or moral codes, leading in a perversion of justice and fairness.

It's worth noting that countries with abundant natural wealth seem to be the world's wellspring for corruption. Corruption is normally a stumbling block for certain nations. Corruption is morally, legally, and socially problematic. Duke \& Agbaji (2017:3) viewed corruption from both the private and public domains, according to them corruption is "characterized as all kinds of deviant or immoral behavior, malfeasance, and other unlawful use of authority, ranging from the granting and accepting of financial benefits to the cover-up of assets and properties gained illegitimately.” It also involves non-financial incentives for individuals, relations, party, or nationwide gains that change the culture that governs imposing roles, practices, and lawful sanctions structures (Duke \& Agbaji, 2017). 
In the same vein Balasa (1985: 28) sees Corruption as a "daunting impediment to long-term growth, a barrier to health care, schooling, and poverty reduction, and a threat to the environment.” By 2015, the Millennium Development Goal of reducing the amount of people below the poverty line will have been accomplished is being seriously hampered by corruption. Although the definition and forms of corruption are still debated in many ways, we agree some universal generalizations can be drawn from the preceding. Which are:

- Because of the variances in human behaviour at different periods and places, corruption has a variety of origins and forms;

- Corruption is an immoral act that goes against established trust and ethical standards;

- $\quad$ It is widespread, as it exists in both the formal and informal sectors;

- Its goal is personal or group advancement at the expense of society as a whole;

- Its advantages would not be restricted to monetary benefits;

- $\quad$ Under the current legal system, the act is deemed unlawful and punished; and

- Corruption is a hindrance to growth and development (Duke \& Agbaji, 2017:3).

Political corruption occurs when decision makers, policymakers, and those who implement the laws participate in the types of unethical activities mentioned within the domain of leadership and the exercise of government power. When laws and regulations are made for the benefit of politicians and their self-interests, corruption exists. Policymaking, democratic institutions, governance, laws, regulations, and orderly processes are all affected and distorted by political corruption in practice (Amundsen, 1997). Similarly, Oghuvbu \& Oghuvbu (2020: 90) see “corruption as the use of legislative powers by government officials for personal gains or unlawful personal gain.” It has tarnished the government's image, weakened its prestige, and lowered the effectiveness of policies and development programs, as well as weakening the economy. This concept of corruption according to Oghuvbu \& Oghuvbu (2020:90) looked at corruption from the political point of view and how politicians use their positions to enrich themselves via unlawful means. Political corruption, according to the fundamental assumption, happens when public office is used to obtain personal gain and the citizenry are neglected (Garner, 2004; Neild, 2002). When a material or immaterial advantage is anticipated, such as money, social status, or political influence, corrupt practices occurs. When elected officers take decisions that benefit their families or ethnic group at the expense of other members of the public, they are engaging in corruption (Oghuvbu \& Oghuvbu, 2020: 90). The focus of this article is on the public domain, especially the interface between the public and private sectors, as well as where political actors engage in corrupt behaviour.

\section{Types and Causes of Corruption in Nigeria}

For any significant change in an economy to be achieved in the fight against corruption, the government must be aggressive, which has been described as the primary cause of the current economic crisis in Nigeria's fourth republic. Corruption, no matter what form it takes or what name it goes by, must be defined, known, and dealt with seriously. As a result, the economy is at risk of stagnation and regression. When it comes to comprehending corruption, 'vertical corruption,' which includes decision-makers and managers, is one example of corruption found by Konie (2003) cited in Rotimi et al., 
(2013:5). Horizontal corruption, which includes the whole official, laymen class, and educated in a country, is more prevalent in less developed countries (Rotimi, et al., 2013) like Nigeria. The reasons why corruption is prevalent in Nigeria have been attributed to a variety of factors, including political style, cultural structure, and a poor legal system. Due to a regulatory system that is both poor and corrupt. According to Ajie \& Wokekoro (2012) cited in Adagbabiri \& Okolie (2018 : 45) "the proliferation of soft state and unaccountable leadership, poor structures of government and informal structure, incursion of politics into the administration, and a fragmented legal system are all causes for corruption in the region, lack of national engagement and focus, lack of probity, transparency, and responsibility, breakdown of social and governmental enforcement systems, large disparities in wealth allocation, low incomes, and bad working conditions, With little benefits and rewards for successful performance, pervasive poverty and tradition, and a strange belief system.” Oghuvbu \& Oghuvbu (2020: 91) argued that in "a nation with a weak economic situation, there is a risk for the country to have a high degree of corruption, which worsens growth rates. They also backed up their claim that a nation with strong macroeconomic output is more likely to have low corruption progress quickly." This supports Benjamin's (2007) cited Rotimi (2013: 5) concluded that a barrier to economic success is a barrier to economic opportunity. This unethical activity is clearly seen on our high and express ways, where law enforcement unlawfully blocks the high ways, extorting money and other valuables from road users while sometimes triggering unintentional accidents that result in the deaths of innocent people.

Ngwube \& Okoli (2013:97-98) espoused that "in Nigeria, the causes for corruption range from non-conformity to religious values, ideals imparted to our culture, philosophies and theories unfamiliar to our society, race that promotes favouritism and nepotism, and a weak legal system that is honoured in breach rather than observance. Poverty, illiteracy, get-richmania, statism, and an erroneous mentality toward public land, as well as a lack of a social net to cushion the effects of jobs, retirement, big households, and the quest for double standards of authority and a poor degree of patriotism" are some of the other triggers of corruption in Nigeria'. It's relevant in itself; poverty seems to be the single most critical force encouraging the widespread distribution of the country's illegal financial inducements to give and take bribes. Okolie (2013:99) "Nigeria must be one of the few places in the world where a man's source of income has little bearing on his neighbour, the general population, or the government. Religious bodies, social clubs, communities and other private entities routinely reward rich individuals who are considered to be corrupt.

Despite the fact that traditional traditions of paying reverence to leaders are often misunderstood, this also contributes to polite corruption, as described by Brows Berger (1983), the degree of such dishonesty in Nigeria is comparatively insignificant. This ensures even those who profit from these dishonest people's greatness seldom doubt them. Another cause of corruption in Nigeria is bad compliance on the part of mechanisms for government regulation. According to Igiebor (2019:499), "Nigeria's transverse agencies and government anti-corruption initiatives have been unsuccessful, and the country remains highly corrupt according to the global corruption index, ranking 144th out of 180 countries in the Transparency International (TI) index in 2018.” The 'Electoral Act' (2010) in Nigeria, according to Krishnan (2020:98), sets a limit on expenditures for specific elective positions by candidates and political parties. The overall limits are set at 1 billion for presidential candidates, and candidates for the Senate and House of Representatives are 
set at 40 million Naira and 20 million Naira, respectively Igiebor (2019:500-501) went on to say that one of the reasons for corruption in the political system is the high cost of obtaining party nomination forms for political offices in Nigeria. For example, the People's Democratic Party (PDP) presidential candidates in the 2015 general election cost 22 million Naira, Senate seat forms cost over 2 million and a little above 1 million Naira respectively, while the governor-ship was 11 million Naira (Igiebor, 2019:501).

\section{Concept of Economic Development}

Development as a concept is a contentious one. It's comparative and multidimensional, and as a result, it can be used in context. Where it comes to modern cultures, the idea of creation is often dichotomized. Some countries are classified as developed, while others are classified as developing. The ranking shows a country's level of growth over time in comparison to others. Some academics, politicians, and experts appear to conflate development with economic growth, as measured by Gross domestic product (GDP) or per capita income (Ettah, 2012:35). Chêne (2014) tend to emphasize systemic reforms as a major component of growth, arguing that changes in inequality, poverty, unemployment, and access to essential social services must all be part of that progress among others. While Abuiyada (2018: 115) views development as "the conditions for realizing the human personality". As a result, three linked criteria must be considered in its evaluation: where there has been a reduction in unemployment, inequality and poverty.

Ettah on the other hand, (2012:36) described development as "the sustained elevation of a community and social structure toward a "higher" or "more civilized" existence." Pearson (1992) considers development as the "increase in the use of available resources, whether quantitatively, qualitatively, or both.” He also claims that evolution does not imply a singular point of view on economic, political, or social progress. Rather, it's a catch-all term for a range of ways to transforming current socioeconomic and environmental conditions into ideal ones. While according to Rodney (1972:9), development involves "increased capability and ability, more autonomy, innovation, increased self-discipline, accountability, and enhanced material well-being.” At least three fundamental principles underpin all economic development. Which are:

- Life sustenance: the ability to satisfy fundamental needs such as clothing, housing, and food;

- Self-esteem: the ability to value oneself as a person; and

- $\quad$ Liberation from servitude: the ability to make choices.

For most development experts, in order to achieve progress, the political system must be in place. According to Almond \& Powell (1966), growth is conceivable when the political system can articulate and aggregate public interests, allocate resources, and maintain law and order only through well-functioning structures. According to Almond and Powell, democratic society is built through the implementation of democratic institutions and modes of action that facilitate the attainment of quality economic and social development goals. The term "social growth" refers to the process by which social norms and institutions evolve over time, resulting in new ones (Adeniyi, 1999). Economic growth is most commonly described as an improvement in people's overall living standards in a given society. Economic growth is commonly described as the achievement of AngloEuropean modernization ideals, which include an increase in production of capital and 
consumer products, as well as some degree of improved economic and social equality, institutional changes, and the embrace of capitalist economic values are all required (Falodun, Omogiagor, \& Ezeaku, 1997). Any culture that wants and seeks economic development will be based on the following core values:

- Raise living standard via the creation of more jobs, quality education, and a stronger focus on cultural and human values, all of which will contribute to increased individual and national self-esteem as well as material well-being;

- Increase people's economic and social options by liberating them from enslavement and overreliance, not only in relation to other people and nation - state, but also in relation to forces of ignorance and untold suffering and

- To enhance the availability and spread of fundamental life-sustaining goods like shelter, health, protection, clothes, and food (Todaro \& Smith, 2003:23).

The World Bank (1994:4) therefore, noted that: "The goal of development is to improve the quality of life of the citizenry, especially in developing countries. Better schooling, a higher level of health and wellbeing, less hunger, greater social independence, and a richer cultural life are all factors that contribute to a higher quality of life.”

\section{Established Institutions to Curb Corruption by Nigerian Leaders}

The relentless rise of corruption has required the implementation of anti-corruption measures interventions and policies by various administrations to combat the problem at the source. This involves the creation of departments, councils, and other organizations tasked with preventing corruption. It also includes programs aimed at reducing corruption to the minimum level. Below are the bodies and initiatives:

- $\quad$ The Economic and Financial Crimes Commission (EFCC) was created in 2003 to complement Obasanjo's administration's anti-corruption crusade. The Economic and Financial Crimes Commission Establishment Act created the anti-corruption agency in 2004. The EFCC is charged with combating financial and economic offences under this Act. The Commission is tasked with administering the terms of other statutes and legislation pertaining to economic and financial crimes, such as the Economic and Financial Crimes Commission Establishment Act, as well as preventing, investigating, prosecuting, and penalizing economic and financial crimes (2004), The Advance Fee Fraud and Other Fraud Related Offences Act 1995, The Failed Banks (Recovery of Debts) and Financial Malpractices of Banks Act 1995, The Money Laundering (Prohibition) Act 2004, The Failed Banks (Recovery of Debts) and Financial Malpractice. The Banks and Other Financial Institutions Act of 1991, as well as the Miscellaneous Offences Act, were all enacted in 1994;

- The Independent Corrupt Practices Commission and Other Related Offences Act, which eventually gave birth to the ICPC, was promulgated in 2000 as a result of the failure to include the private sector, which is also corrupt, in all of these laws;

The Nigerian constitution of 1979 established the Code of Conduct Bureau Tribunal, which receives allegations about unethical practices. The Bureau prohibits elected officials from accepting remuneration for two public offices at the same time and from engaging in private practice while employed by the government, the code prohibits public servants from accepting gifts or in-kind benefits for themselves or others as a result 
of anything done or omitted in the performance of their duties. It makes it illegal for elected officials to have or operate international bank accounts. Public officials must register their personal properties and those of their spouses shortly after assuming office, every four years, and at the end of their terms;

- Nigerian Extractive Industries Transparency Initiative (NEITI);

- $\quad$ Budget Monitoring and Price Intelligence Unit (BMPIU) and

- Nigerian Investment Promotion Commission (NIPC) (Alege, Adamu \& Muhammad, 2014: 211; Rotimi, Obasaju, Lawal \& Iseolorunkanmi, 2013: 7).

\section{Programmes and Initiatives}

The Shagari Second Republic, introduced the Ethical Re-orientation Campaign (ERC). Buhari/Idiagbon regime, War against Indiscipline (WAI). Babangida's Committee on Corruption and other Economic Crimes (CCEC) and War against (WAC) Corruption.

General Sanni Abacha regime introduced the War against Indiscipline and Corruption (WAIC).

Whistle-Blowing was introduced under Buhari/Osinbajo's government as an anticorruption policy to fight against corruption in Nigeria (Rotimi, Obasaju, Lawal \& Iseolorunkanmi, 2013: 8; Abuiyada, 2018: 115).

Other attempts include the formation of investigation committees, commissions of inquiry, and tribunals (such as the Failed Bank Tribunal) to pursue dishonest individuals. To support inquiry commissions and tribunals, laws such as the Money Laundering Act of 2003, the Advance Fee Fraud and Fraud Related Offences Act of 1995, the Foreign Exchange Act of 1995, and the Corrupt Practices and Other Related Offences Act of 2000 were passed (Alege, Adamu \& Muhammad, 2014: 211; Rotimi, Obasaju, Lawal \& Iseolorunkanmi, 2013: 8; Abuiyada, 2018: 115).

\section{Theoretical Framework}

Major proponents of the elite theory are 'Vilfredo Pareto (1848-1923), Gaetano Mosca (1858-1941), and Roberto Michel's (1876-1936).' The elite theory can be used to explain dominance of corrupt practices in Nigeria. The elite theoretical viewpoint emphasizes a society's leadership and how it influences socioeconomic and governance matters (Igiebor, 2019). The words 'elite' and 'elites' denote someone in a culture who wields undue political, social, or economic power as a result of their exposure, skills, relationships, education, and material wealth (Bottomore, 1976; Nwankwo, 1997; Parry, 1976). They are a privileged minority with leadership skills, aspirations for leadership, access to key bodies of knowledge and intelligence. They play dominant roles in orchestrating policy agendas and setting political goals in the political realm (Igiebor, 2019). Ihonvbere (2009) espoused that the elites control societies political and economic systems, they also establish and maintain societies ideological sphere, particularly through force.

The character of colonial Nigeria formed the origins and growth of Nigeria's elites. The elites who rose to power as political leaders in postcolonial Nigeria during the decolonization era did not stray far from the colonial regime's development philosophy, as evidenced by the postcolonial repression of the people of Nigeria (Igiebor, 2019). 
Government is a tool to achieve a goal by Nigeria's elites, who see it as a means to enrich themselves by unethical practices rather than true nation building. As a result, rather than taking the lead to promote quality leadership as is expected in any country, they have continued to obstruct Nigeria's democratization (Enemuo \& Momoh, 1999). From an elite theoretical viewpoint, one can deduce that corruption in Nigeria is cultivated from the top down. In terms of leadership, Nigeria has a long history of being regarded as corrupt. After leaving government, a large number of public officials, particularly those in political office, have become extremely wealthy (Adedoja, 2013). The social strata have been corrupted by a system of non-accountability. Politicians are using their control of administrative power for personal gain without been accountable to the public and in turn affecting Nigeria's economic development negatively (GFI, 2013).

\section{The Effects of Corruption on Economic Development}

In some economies, excessive rigidity and bureaucracy can wreak havoc, make investment difficult and enterprises unprofitable. Some scholars and practitioners believe that corruption has the potential to liberalize hierarchical administrative processes and foster businesses. In the presence of structural corruption, some countries' economic growth rates seem unaffected due to the degree of commercial activity for years has been tightly regulated, whereas corruption prevents development and growth in others (Ugur \& Nandini, 2011). The general consensus on the impact of corruption on commercial development is as a result of the discouragement due to international investment and foreign assistance while also impeding domestic private investment, entrepreneurship, and planning. As a result, corruption reduces business prospects and slows economic development (Chêne, 2014; Epele, 2006). In regions of Nigeria, there is still insurgency and political unrest which exacerbates the problem.

Corruption also has an effect on government spending habits. Government funds are dedicated mostly to 'vanity schemes' and programs that are vast and impossible to handle by state authorities in countries where corruption is heavy, rather than to vibrant community societal agendas such as health, education, Airports, roads, and other infrastructure schemes are examples of such programs (Shuaib, 2015: 30). Corruption is a significant impediment to the successful mobilization and deployment of capital in Nigeria; as a result, resources are diverted from critical programs and initiatives that can alleviate lack and promote development economically. The domestic financial system is been weaken by corruption, which is harmful to productivity because it lowers investment and savings, lowering people's living standards (Igiebor, 2019; Nwabueze, 2020: 504). Wealth obtained by fraudulent dealings in Nigeria are either transferred out of the country to international investments and bank accounts in overseas companies, or consumed on the import of extravagances for individual usage. The allegations of a former Nigerian minister looting \$6 billion into foreign banks, and a onetime governor who stole $\$ 77$ million and was sent to jail for money laundering of international bank accounts testify to the above view (BBC, 2012; BBC, 2015; Adeyemi, 2016; Nnochiri, 2016). Corruption raises a government's spending contributions and operating expenses, as well as tax leakage and the money available for public programs. Nigeria has lost almost $\$ 400$ billion to corruption since attaining political independence in the early 1960s, according to Dr. Obiageli Ezekwesili, a former World Bank Vice President for Africa (Okoye, 2012). Political 
bribery, political activity, and election fraud account for the majority of the funds gained by unethical practices in Nigeria (Igiebor, 2019:505).

Corruption causes poverty by transferring government resources meant for economic development, poverty alleviation, and human capacity development to the personal advantage of corrupt officials and their clientele. Because they cannot afford to pay bribes and do not profit from corrupt governments' initiatives, low-income earners are disproportionately disadvantaged by corruption (Nwabueze, 2020). This has contributed to the breakdown of state institutions, poverty, unemployment, revenue loss, and development failures. As a result, Nigeria's high poverty rate has been connected to the political class's widespread corruption, resulting in immeasurable hardship for the majority of Nigerians throughout time. Despite its abundant resources and robust oil and gas production sector, Nigeria was named one of the world's most unequal and poor countries by the 2016 CCA in September, with far more than 80 million of the nation's 186 million people living in poverty (Igiebor, 2019:506). Egwuatu (2020) therefore, noted that over 102 million Nigerians are extremely poor in 2020 and it's expected to reach 150 million in the following year while in the fourth quarter of 2020, joblessness for people aged 15-24 was 53.4 percent, for people aged 25-34 was 37.2 percent. Women had a 35.2 percent of people without jobs compared to 31.8 percent for males.” The country's unemployment rate, which is the second highest in the world, is extremely disturbing. (Egwuatu, 2020; O’Neill, 2021; Niyi, 2021).

Nigeria ranked 25\% out of a possible $100 \%$ on the Corruption Perception Index published in January 2021, putting it in the bottom half of all international indices. Except for 2013, when it received a $25 \%$, this is the lowest ranking the nation has received since the global assessment began in 2012 (Niyi, 2021; O’Neill, 2021). Corruption is linked to poor control of public finances as well as the distribution of public goods, and it reduces ordinary living standards. For instance in the Human Development Index (HDI) ranking released in 2020 Nigeria drops 3 places to 161 in 2019 as against 158 in 2018 among 189 countries (Oluwabunmi, 2020). This means Nigeria is within the level nations with a poor human development index.

\section{Conclusion and Recommendations}

This paper has investigated the challenges corruption has brought and its pervasiveness in Nigeria's political structure. It shows that there is a negative relationship between corruption and economic development, and if strict measures are not taken to combat it, the country's progress will be hampered. Corrupt governments are still doomed to fail. Corruption, defined as monopoly plus discretion without transparency, is a major impediment to long-term development, particularly in developing countries like Nigeria. It has looted the resources of resource-rich countries such as Nigeria, trapping people in poverty and leading to high rate of unemployment. Even if certain people seem to benefit from the paying of a bribe by the majority of people, the net impact of corruption on economic growth and development remains negative. The slower a country's economic development is, the more dishonest it becomes. As a result, it is self-evident that in order to reduce corruption and restore the economy's reputation and prestige, as well as create an atmosphere conducive to accelerated economic development, the perceived concerns and 
problems of corruption that are slowing down the economy must be seriously addressed appropriately. It's on this note the study recommends the following:

- It is necessary for government to provide sufficient funding to anti-corruption agencies like the EFCC, ICPC, and for the government to refrain from interfering with the mandates provided to these agencies in order for them to be successful. The anti-corruption agencies will not be able to endure the opposition powers of the criminal fundamentals in the nation except the government is prepared to devote enough resources to finance and run the agencies, leaving them fully autonomous.

- For Nigeria to be successful in the struggle against corruption, the root causes of corruption has to be addressed and this has to be through the effective implementation of legal mechanism in place.

- Citizenry and those in position of power should be enlightened to discourage extreme consumerism and the "get rich quick" mentality have infiltrated the Nigerian system.

- Nigerian leaders must at all times be willing to discover and penalize corrupt officials and citizens, as well as to foster an economic climate that will enhance Nigerians' living standards.

- Adding these already existing initiatives, disciplinary actions must be implemented to guarantee honesty, accountability, and oversight through an equal and just scheme. This is because certain people will partake in unethical behavior merely because they believe and accept that they will get away with it.

- People with high moral values and a track record of honesty and competence should be allowed to get involved in politics and run for office. This would limit the number of people seeking elected office only for personal gains.

If these recommendations above can be brought into the Nigerian system corruption will be reduced drastically, thereby paving way for economic growth and development in Nigeria's fourth republic.

\section{References}

1. Abuiyada, R. (2018). Traditional development theories have failed to address the needs of the majority of people at grassroots levels with reference to GAD. International Journal of Business and Social Science. 9(9), 115-119. doi:10.30845/ijbss.v9n9p12

2. Adagbabiri, M. M., \& Okolie, U.C. (2016). "Corruption and national development: An examination of Nigeria’s fourth republic”. Journal of Strategic \& Development Studies, 1(1).

3. Adagbabiri, M. M., \& Okolie, U.C. (2018). Corruption and the challenges of insecurity in Nigeria's fourth republic. Journal of Political Science and Leadership Research, 4, 41-56.

4. Adedoja, T. (2013). US report: There's massive corruption in Nigeria. This Day Live. Retrieved from http://allafrica.com/view/group/main/main/id/00024107. html on the 12-5-2021.

5. Adeniyi, O. B. E. (1999). Education and national development. Journal of Art and Social Sciences, 1(2), 56-63.

6. Adetayo, O.A. (2019). Relationships between corruption and terrorism in African countries. Open Journal of Economics and Commerce. 2, 21-32.

7. Adeyemi, O. (2016). 10 biggest corruption cases that shook Nigeria in 2015. Nigeria: Green News Publication. Retrieved from https://soapboxie.com/ world-politics/Corruption-in-Nigeria

8. Alege, S.O., Adamu, M. \& Muhammad, S.A. (2014). Effects of corruption on economic development in Nigeria. Global Journal of Interdisciplinary Social Sciences. 3(3), 209-215. 
9. Almond, A. G., \& Powell, G. B. (1966). Comparative politics: A developmental approach. Boston, MA: Little Brown and Co.

10. Amundsen, I. (1997). Political corruption: An introduction to the issues (Working Paper 99:7). Bergen: Chr. Michelsen Institute

11. Ayandele, E. A. (1974). The educated elite in Nigerian society. Ibadan: Ibadan University Press.

12. Asandului, M., Lupu, D., Maha, L. G., \& Viorică, D. (2021). The asymmetric effects of fiscal policy on inflation and economic activity in post-communist European countries. Post-Communist Economies. https://doi.org/10.1080/14631377.2020.1867430

13. Balasa, B. (1985). "Exports, policy choices, and economic growth in developing countries after the 1973 oil shock." Journal of Development Economics. 18, 22-35. https://doi.org/10.1016/03043878(85)90004-5

14. Balcerowicz L., (2001) Libertate şi dezvoltare. economia pieţei libere, multiprint Publishing House,

Iasi

15. BBC, (2012). Former Nigeria governor James ibori jailed for 13 years. Retrieved from Former Nigeria governor James Ibori jailed for 13 years - BBC News on the 13-05-2021.

16. BBC, (2015). Nigerian former minister 'stole $\$ 6 \mathrm{bn}$ of public money.' Retrieved from Nigerian former minister 'stole \$6bn of public money' - BBC News on the 13-05-2021.

17. Bottomore, T. B. (1976). Elites and society. Harmondsworth: Middlesex Penguin Books.

18. Burke, S. (1993). People first - A guide to self - reliance participatory rural development, Zed Books, London. Dike, V. 2004. Corruption in Nigeria: A new paradigm for effective control, htt://www.africaneconomicanalysis.org/article/gen/corruptiondikeht. Accessed on the 13/05/2021.

19. Chêne, M. (2014). The impact of corruption on growth and inequality. Berlin: Transparency International, Anti-Corruption Helpdesk.

20. Dike, V.E. (2005). Corruption in Nigeria: A new paradigm for effective control. Africa Economic Analysis. $\quad$ Retrieved $\quad$ on $\quad 1 s t \quad$ August 2007 from http://www.jsdafrica.com/Jsda/Summer1999/articlespdf/ARC\%20\%20A\%20Psychological\%20Analysis\% 20of\%20Corruption\%20in\%20Nigeria.pd

21. Duke, O. \& Agbaji, D. (2017). Corruption and the challenges of boko haram terrorism in Nigeria: A case of the Nigerian armed forces. Asian Journal of Arts \& Social Sciences. 4(2), $1-20 . \quad$ DOI: 10.9734/ARJASS/2017/34025

22. Egwuatu, P. (2020). Population of extremely poor persons in Nigeria hits 102m — Retrieved from NECA Read more at: https://www.vanguardngr.com/2020/10/population-of-extremely-poorpersons-innigeria-hits-102m-neca-2/ on the 13-05-2021.

23. Ekone, F.A. \& Amaghinoyeodiwe, I.A. (2020). Does corruption cause economic growth in Nigeria? Journal of Management, Economic, and Industrial Organization. 4(2), 89-108.

24. Enemuo, F., \& Momoh, A. (1999). Civil associations in Nigeria: Politics of transition and governance 1986-1996. O. Oyediran \& A. Agbaje (Eds.) (73-104). Great Britain: Russell Press Limited.

25. Epele, A. (2006). Corruption and the Nigerian society: Causes, effects and the futility of solutions. The Politics Magazine. Benin City: University of Benin

26. Ettah, B.E. (2012). Corruption and economic development in Nigeria: A materialistic observation. Journal of Economics and Sustainable Development. 3(14), 34-48.

27. Falodun, A. B., Omogiagor, N., \& Ezeaku, L. C. (1997). Roundup economics for senior secondary certificate examination. Lagos: Longman.

28. Garner, B. (2004). Black’s law dictionary (8th ed.). Eagan, MN: Thompson West.

29. Geraint, P. (1969). The political elites. London, UK: George Allen and Unwin.

30. Global Financial Integrity (GFI). (2013). Financial flows cost Nigeria \$130b. Retrieved from File:///E:/illicit.CSP.htm. On the 12th 05- 2021.

31. Igiebor, G.O. (2019). Political corruption in Nigeria: Implications for economic development in the fourth republic. Journal of Developing Societies. 35, 493-513.

32. Ihonvbere, J. (2009). Leadership and the future of Nigeria. Valley Forge, PA: Vanguard.

33. Ikelegbe, A. O. (1994). Public policy making and analysis. London, UK: Uri Publishing Ltd.

34. Johnson, R. A., \& Sharma, S. (2004). About corruption. In R. A. Johnson (Ed.), the struggle against corruption: A comparative study (1-19). New York, NY: Palgrave Macmillan

35. Kew, D. (2006). Nigeria. In Sanja Tatic (Ed.), Countries at the crossroads. New York, NY: Freedom House 
36. Krishnan, J.K. (2020). International lawyers as disrupters of corruption: Business and human rights in Africa's most populous country-Nigeria. Northern Journal of Human Rights. 18, 93-135.

37. Madichie, N. O. (2005). Corruption in Nigeria: how effective is the corruption perception index in highlighting the economic malaise? World Review of Science, Technology and Sustainable Development. $2(3 / 4), 320-335$.

38. Maduagwe, M. O. (1996). Nigeria in search of political culture. The political class, corruption and democratization Nigeria. 13, 18-19 (Alex Gboyega ed., 1996).

39. Neild, R. (2002). Public corruption: The dark side of the social revolution. London, UK: Anthem Press.

40. Ngwube, A., \& Oko0li, C. (2013). "The role of the economic financial crime commission in the fight against corruption in Nigeria”. Journal of Studies in Social Sciences, 4 (1).

41. Niyi, A. (2021). Assessing Nigeria from within and without. Retrieved from Assessing Nigeria from within and without | The Nation News Nigeria (thenationonlineng.net) on the 13-5-2021.

42. Nnochiri, I. (2016). Money laundering: EFCC recovers looted \$2trn in 12 years. Vanguard, February 3, 2016. Retrieved from http://www.vanguardngr. com/2016/02/money-laundering-efcc-recovers-looted2trn-in-12-years/ on the 13-5-2021.

43. Nwankwo, A. A. (1997). On the brink of disaster: Nigerian ethos and meaning of the tragic state. Enugu: Fourth Dimension Publishers.

44. O’Neill, A. (2021). Nigeria: Unemployment rate from 1999 to 2020. Retrieved from Nigeria unemployment rate 2020 | Statista on the 13-05-2021.

45. Oghuvbu, E.A. \& Oghuvbu, B.O. (2020). Corruption and the lingering of insecurity challenges in Nigeria's. Journal of Public Administration, Finance and Law. 18, 88-99.

46. Okenna, N. P. (2020). Impact of corruption on Nigeria's economic development. International Journal of Engineering Applied Sciences and Technology. 3, 39-44.

47. Okoye, R. (2012). Nigeria has lost $\$ 400 \mathrm{bn}$ oil revenue to corruption since Independence Ezekwesili. Retrieved from Nigeria has lost $\$ 400 \mathrm{bn}$ oil revenue to corruption since Independence Ezekwesili - Daily Post Nigeria on the 13-5-2021.

48. Oluwabunmi, B. (2020). Nigeria drops 3 places to 161 in UN's 2020 human development index. Retrieved from Nigeria Nigeria drops 3 places to 161 in UN's 2020 human development index - Businessday NG on the 13-05-2021.

49. Parry, G. (1976). Political elite. London: George Allen and Unwin.

50. Pearson, R. (2000). Rethinking gender matters in developmente, in allen, T. \& Thomas, A. (eds.). Poverty and Development into the 21st Century. Oxford: Oxford University Press.

51. Post, K., \& Vickers, M. (1973). Structure and conflict in Nigeria 1960-1966. Madison, WI: University of Wisconsin Press.

52. Rodney, W. (1972). How Europe underdeveloped Africa, Bogle-L'ouerture Publishers, London.

53. Rotimi, E.M., Obasaju, B., Lawal, A. \& Iseolonunkanmi, J. (2013). Analysis of corruption and economic, Afro Asian Journal of Social Sciences. 4, 1-19.

54. Shuaib, O.M. (2015). Corruption in Nigeria: Causes, effects and probable solutions. Journal of Political Science and Leadership Research. 22-36.

55. Sklar, R. L., Onwudiwe, E., \& Kew, D. (2006). Nigeria: Completing obasanjo's legacy. Journal of Democracy. 17(3), 100-115.

56. Transparency International (2020). “Corruption Index”, various series. Sourced from Corruption Perceptions Index: Nigeria is 149 of 183 countriese- CISLAC (vanguardngr.com) accessed on the 27th-42021.

57. Ugur, M., \& Nandini, D. (2011). Evidence on the economic growth impacts of corruption in lowincome countries and beyond. London: EPPI-Centre, Social Science Research Unit, Institute of Education, University of London.

58. World Bank .1991. World Bank report, Oxford University Press, New York.

59. World Bank. (1997). Helping developing countries combat corruption: The role of the World Bank (39-51). New York, NY: Oxford University Press Crimes in Nigeria. 